\title{
Calculating Visions: Civil Rights Legislation in the Kennedy and Johnson Years
}

The presidential years of John F. Kennedy and Lyndon B. Johnson are synonymous with the culmination of the Second Reconstruction. This study examines the civil rights legislative strategies of presidents Kennedy and Johnson as they dealt with what became the Civil Rights Act of 1964 and Voting Rights Act of 1965.

Betty Glad notes that an understanding of the American presidency requires an emphasis on "the contextual factors that define the office and the behavior of its incumbents at particular points in time." In addition, there are several general underlying constants of political behavior that operate as presidents and would-be presidents maneuver in the political arena. First, presidents are politically rational actors, and election and reelection set the parameters of political rationality. That is, as Anthony Downs states it, within the constraints of the resources and information available, politicians "formulate policies in order to win elections, rather than win elections in order to formulate policies." 2 Politicians may well act upon their conception of the public interest, or from their own private sense of what is best for their constituents with respect to a particular issue, but they do so within the constraint of the overriding need for election or reelection. Politicians deal with issues so as to optimize their chances for electoral success. The fundamental process that brings issues to the politician's attention is elections. ${ }^{3}$

Second, issues are manipulated by politicians in their pursuit of office. Jack Walker argues that there is an "agenda of controversy" at any given time to which political actors pay attention, and it is extremely difficult to change this agenda. ${ }^{4}$ But, as E. E. Schattschneider notes, the ability to manipulate the "agenda of controversy" is an essential skill of political

JOURNAL OF POLICY HISTORY, Vol. 5, No. 2, 1993.

Copyright (C) 1993 The Pennsylvania State University Press, University Park, PA. 
leaders. The public's political attention is limited and the shaping of that attention span is critical. "Some issues," Schattschneider maintains, "are organized into politics while others are organized out." This is the crux of the "mobilization of bias." Crises, windows of opportunity, and interestgroup activity may all play a role in bringing issues to the attention of politicians and the public, but ultimately it is the political decision-maker who must decide how the issue is dealt with on the government agenda. ${ }^{6}$

Finally, politicians are constantly preoccupied with creating, maintaining, and re-creating winning political coalitions. The struggle to win office is followed by the successful candidate's struggle to achieve legislative success. In each instance, coalition building is the key to victory. At the heart of the coalition-building process are two fundamental facts of political life: (1) the instability of alliances and (2) the role of issues in creating new alliances. ${ }^{7}$

John Kennedy and Lyndon Johnson were both successful, experienced politicians before they came to the presidency. The issue of civil rights was a central legislative concern to both of their administrations. By 1960 , in the wake of the events of the 1950s and the civil rights sit-ins that began in that year, the public outside the South overwhelmingly supported the desegregation of public schools, public transportation facilities, and restaurants. Civil rights remained the most important issue in the public eye between the years 1960 and $1965 .{ }^{8}$ It was also the issue that most insistently threatened to split apart the Democratic party coalition that was forged in the New Deal years. To this day the civil rights issue threatens the maintenance of the New Deal coalition. ${ }^{9}$

This study examines the conditions that led to presidential action on civil rights legislation in the Kennedy-Johnson years, up through 1965. It explores the political setting, and its shifts, on presidential action, as well as the particular backgrounds, styles, and abilities of each president as these factors affected their civil rights legislative strategies and actions.

\section{The Kennedy Years}

Two words, continuity and caution, reflect the Kennedy administration's approach to civil rights in general and civil rights legislation in particular. The literature on Kennedy and civil rights has grown over the years, and both the supporters and the opponents of the administration agree there was a reluctance to pursue legislative action in this area, despite repeated calls for such action. ${ }^{10}$ The Kennedy administration maintained continuity with the previous administration's handling of civil rights in the legisla- 
tive arena. The Eisenhower administration initially hesitated in its introduction of what was to become the Civil Rights Act of 1957, and it supported only a very weak Civil Rights Act of 1960 . As opposition to a strong civil rights bill mounted in the Senate in 1957, President Eisenhower publicly withdrew his support from the most critical section of the proposal, Title III. ${ }^{11} \mathrm{~A}$ weakened bill was passed and signed into law that year, and the Eisenhower administration never attempted to reintroduce the elements that had been removed from the 1957 legislative package.

On 1 September 1960 John Kennedy officially kicked off his general election campaign for the presidency with a speech that included a call for Representative Emanuel Celler of New York and Senator Joseph Clark of Pennsylvania to "prepare a comprehensive civil rights bill, embodying our platform commitments, for introduction at the beginning of the next session [of Congress]." 12 This was JFK's response to the liberals' disenchantment with his placement of Lyndon Johnson on the Democratic ticket. Johnson ranked second to Nixon in the eyes of many liberal Democrats as the politician they loved to hate. The members of the National Board of the Americans for Democratic Action, a staunch liberal group, seriously considered withholding their endorsement from the Kennedy-Johnson ticket. Arthur Schlesinger, Jr., a member of the board and a Kennedy ally, wrote to the Democratic presidential nominee, "As someone [at the board meeting] put it, 'We don't trust Kennedy and we don't like Johnson; but Nixon is so terrible that we have to endorse the Democrats.' "13 The liberals were galvanized by Kennedy's support for civil rights legislation and his efforts on behalf of Martin Luther King, Jr., during the latter part of the campaign. The liberal icon, Eleanor Roosevelt, who had previously publicly voiced her qualms about JFK, now said, "I don't think anyone in our politics since Franklin [Roosevelt] has had the same vital relationship with crowds . . . his intelligence and courage elicit emotions from his crowds."14

But once elected to office Kennedy felt he could not move to fulfill his pledge for civil rights legislation. Southerners controlled a majority of the congressional committees, and he believed that they would defeat any proposal his administration would bring forward as well as wreck havoc on the rest of his program in retaliation for his support of civil rights. He also believed that he had no mandate to go forward with a call for controversial legislation, given that he had won the presidency by the slimmest of vote margins. A House vote early in 1961 to enlarge the Rules Committee so that the president would have a working majority on the committee narrowly passed by a 217 to 212 vote, with 64 , mainly southern Democrats, opposed. The president and his staff, as well as Speaker Sam 
Rayburn, had all lobbied intensively for the Rules Committee enlargement. The president interpreted the vote as a call for him to be wary of the South's power. "With all that going for us," JFK lamented, "with Speaker Rayburn's own reputation at stake, with all the pressures and appeals a new President could make, we won by five votes. That shows you what we are up against." 15 Speaker Rayburn saw it differently. He had little respect for the young president's legislative acumen, given JFK's lack of attention to the congressional process when he served in the House and the Senate. "He didn't change a vote," noted the speaker, despite his personal intervention. ${ }^{16}$ Civil rights, from the administration's perspective, had to be placed on the legislative back burner so that other presidential business could be addressed by the Congress.

The Kennedy administration announced that it would send its first civil rights legislative proposals to Congress in February 1963. These proposals were so weak that Martin Luther King, Jr., commented, "If tokenism were our goal this administration has adroitly moved us toward its accomplishment." In light of the negative reaction toward the bill by civil rights supporters, the president, half in jest, called Assistant Attorney General Burke Marshall and asked, "What's this bill of yours and Bobby's?"17

Yet on 12 June 1963 John Kennedy, in a nationwide television address, committed his administration to major new civil rights legislation. "We face . . . a moral crisis as a country and a people. It cannot be met by repressive police action. It cannot be left to increased demonstrations in the streets. It cannot be guided by token moves or talk," he told the nation. "It is time to act in Congress." 18 What had changed his mind? Burke Marshall recalls that within a few days of his return from the civil rights rioting and demonstrations that were engulfing Birmingham, Alabama, "The President became convinced [that he] had to deal with what was clearly an explosion in the racial problem that could not, would not go away." Norbert A. Schlei, head of the Office of Legal Counsel, recalls that Attorney General Robert Kennedy told the top Justice staff, he "believed as a result of this Birmingham thing, the people of this country have really gotten an inkling of what it was like to be a Negro in the South . . . and they were prepared to support something important in the field of civil rights."19 "The essence of Kennedy's civil rights strategy," wrote top JFK aide Theodore Sorensen, "had been to keep at all times one step ahead of the evolving pressures, never to be caught dead in the water."20 The events in Birmingham had pushed the president where, but a month before, he had expressly wished not to go.

Caution, however, was the administration's byword even as it moved into a realm that it proclaimed itself boldly ready to enter. On 12 June 
JFK felt the first sting of retribution to his call for civil rights legislation as eighteen southern representatives reversed their previous votes of support for the administration's Area Redevelopment bill, contributing to a 209208 defeat of the proposal. But black impatience was overflowing into the streets, and this helped to keep the administration's civil rights pledge on track. In the ten weeks following the president's 11 June speech, there were an estimated 758 black protests and pro-civil rights demonstrations in 186 different communities. "Every day that summer," Arthur Schlesinger, Jr., wrote, "new and ominous tendencies seemed to appear in the colored masses." 21 JFK sent his civil rights bill up to the Hill on 19 June 1963. The message that accompanied it included a plea for restraint by black protesters. He argued that "demonstrations have increasingly endangered lives and property, inflamed emotions and unnecessarily divided communities. They are not the way in which this country should rid itself of racial discrimination." Kennedy noted, "This problem is now before the Congress. Unruly tactics or pressures will not help and may hinder the effective consideration of these measures." 22

The president's bill endorsed fair employment legislation but omitted a Fair Employment Practices Commission [FEPC] section. The president's proposal permitted the attorney general to bring suit on behalf of individuals who had been discriminated against with respect to access to public schools, but only in cases where citizens filed written complaints and demonstrated that they could not afford to bring suits on their own. In addition, a discretionary cutoff of federal funds was sought to school districts that maintained discriminatory practices. The administration's proposals also banned discrimination in public accommodations in enterprises having a "substantial effect" on interstate commerce. Finally, the administration bill also called for the creation of a Lyndon Johnson-inspired local conciliation service to permit mediation efforts before racial disputes got out of hand. There was no substantially effective voting-rights element in the bill. James L. Sundquist, a leading scholar of national politics, notes, "It was clear that the counsel of caution had, on the whole, prevailed" in the bill sent forward by the Kennedy administration. ${ }^{23}$

The civil rights lobbyists pushed for a series of additions to the administration's bill: an FEPC section; a section akin to the original Title III in the 1957 Eisenhower proposal, covering all racially discriminatory practices; a comprehensive public-accommodations section; a "Powell"-type mandatory prohibition on federal aid to any school or state agency practicing discrimination; and an administratively directed federal voting registration procedure. They were not enthused by the substance of the administration bill and they were worried about the president's incessant cau- 
tion. As the White House bill was sent to the Hill, John Kennedy asked his brother, "Do you think we did the right thing by sending the legislation up?" Robert Kennedy responded, "It really had to be faced up to."24

On 22 June, two days after most of the major civil rights leaders joined together to announce publicly their plans for a march on Washington to support their demands for legislation and jobs, the president held a meeting with the leaders of the planned march to the White House. He told the group, "It seemed to me a great mistake to announce a march on Washington before the bill was even in committee. The only effect is to create an atmosphere of intimidation - and this may give some members of Congress an out [from supporting it]." The president argued, "Now we are in a new phase [of the civil rights struggle], the legislative phase. . . . To get the votes we need we have, first, to oppose demonstrations which will lead to violence and, second, give Congress a fair chance to work its will." In his closing remarks to the group the president observed, "The Vice President and I know what it will mean if we fail. I have just seen a new poll-national approval of the Administration has just fallen from 60 to 47 percent [this poll has never been found, and all known polls indicate the president maintained a solid majority of national support throughout this period]. We're in this up to the neck. The worst trouble of all would be to lose the fight in Congress. We'll have enough troubles if we win. . . . A good many programs I care about could go down the drain as a result of this-we may go down the drain as a result of this-so we are putting a lot on the line." 25

Caution was the administration's posture as the liberal forces pushed forward with their proposed march and gained the allies they needed for a stronger civil rights bill. "People were talking about sitting in on Capitol Hill and the floor of Congress," one black activist wrote. "They were ready to bring the country to a halt, but . . . before the people knew what was happening, the march was Kennedy-sponsored and proclaimed as being in the American tradition." The march was contained by the Kennedy White House. ${ }^{26}$ It "was awfully disorganized at the beginning of the summer," Burke Marshall recalled. But once the administration decided it could not be headed off, "the Attorney General wanted to make sure it was a success and that it was organized right." 27 Assistant Attorney General John Douglas was assigned full-time to provide logistical support for the march and get it under control. The 28 August march on Washington, originally viewed with great trepidation by the White House, became a celebration of a shared dream. Russell Baker of the New York Times wrote: "Instead of the emotional horde of angry militants that many had feared, what Washington saw was a vast army of quiet, middle-class 
Americans who had come in the spirit of the church outing." 28 The march moved many in the white middle class to embrace the movement, and their children joined it. ${ }^{29}$ The president, fearful of possible disorder, had turned down an invitation to address the marchers. But he congratulated the demonstrators after the march was over and he greeted the march leadership at the White House with a refrain from King's speech, "I have a dream." 30

The president discussed civil rights legislative strategy with the leaders immediately after the march. A. Philip Randolph told JFK, "It is going to take a crusade to win approval of the civil rights measures. It is going to be a crusade that, I think, nobody but you can lead." But neither the president nor the attorney general wished to lead a crusade. "What I want is a bill," Robert Kennedy responded, "not an issue." John Kennedy told the group that a stronger bill would go down to defeat as the Republicans could not be brought along to support it, and they held the votes necessary for passage. ${ }^{31}$

The civil rights lobbyists believed that the president would support the addition of an FEPC provision and a Title III, "But he is hesitant to urge their addition and prefers to leave that decision with Congress." 32 In fact, at the 22 June White House meeting, Vice-President Johnson, with Robert Kennedy present, gave his explicit assent on behalf of the administration, for the civil rights leadership to lobby the Congress in an effort to strengthen the bill. ${ }^{33}$ The civil rights leaders moved to enhance the White House bill. Outside events aided the black rights forces. A bomb blew up a black church in Birmingham during Sunday morning services, killing four children and injuring twenty others. The nation was outraged, and the liberal forces, augmented by a massive church-led lobbying effort, pushed Chairman Celler of the House Judiciary Committee to back a Title III and a strengthened public accommodations section, and these measures as well as other strengthening provisions were added to the bill by the committee. ${ }^{34}$

The White House agents would not accept these additions because they believed this would destroy support for the bill by moderate Republicans. They were cautious in their assessment of what could be the strongest bill that would be acceptable to a majority in the House and the Senate. The administration pressured Celler to back away from the strengthening amendments, and the attorney general went before the committee to ask publicly for them to be rescinded. The committee majority complied with the attorney general's request. ${ }^{35}$ The administration's restraint was met with suspicion by civil rights advocates. Bayard Rustin, a longtime civil rights activist, wrote to Martin Luther King, Jr., in early November 1963, 
"There are few, if any, who claim that the Administration is putting its full weight behind even these measures." 36 The administration, however, was satisfied that it had a bill that would be passed by the House and that had a chance of being passed by the Senate, despite the evident unhappiness of many civil rights advocates and their congressional allies. ${ }^{37}$ On 22 November, an assassin's bullet intervened to put an end to John Kennedy's administration.

\section{The Johnson Years}

Innovation and immediacy, touched with a sense of political aggressiveness, defined Lyndon B. Johnson's presidential approach to civil rights legislation. From the onset of his presidency, Lyndon Johnson had a sense of the immediacy of the need for civil rights legislation that Senator Lyndon Johnson did not have. In the early morning hours of his first day as president, LBJ told two of his close aides, Jack Valenti and Bill Moyers, that his "first priority is passage of the Civil Rights Act." ${ }^{38}$ On 27 November, five days after the assassination, he addressed a joint session of Congress and said movingly: "No memorial or eulogy could more eloquently honor President Kennedy's memory than the earliest possible passage of the civil rights bill for which he fought so long." ${ }^{39}$ Civil rights was the issue that could end the running feud between Johnson and the liberals and provide legitimacy to his presidency. Johnson told his biographer, Doris Kearns, "I knew that if I didn't get in front on this issue they [the liberals] would get me. They'd throw up my background against me. They'd use it to prove I was incapable of bringing unity to the land. . . . I had to produce a civil rights bill even stronger than the one they'd have gotten if Kennedy had lived. Without this, I'd be dead before I could even begin." ${ }^{40}$ Harry McPherson, longtime Johnson aide, recalled, "He knew he could not be a national leader as long as there was any doubt about his commitment to civil rights. ${ }_{41}$

The speed and the manner in which Johnson committed his prestige to passage of the 1964 civil rights proposals surprised his critics. He was usually a politician committed to caution and consultation before he took any action. In the area of civil rights, his legislative record as majority leader was one of constant wariness and compromise. In the past he had to be certain the votes were there before he made a concerted effort to push for any legislation, and he had never been in the forefront of a push for strong civil rights legislation. Now he moved before anyone believed the votes were really there to get the legislation past a Senate filibuster. 
The day after the civil rights bill passed the House, LBJ convened a meeting of his top advisers on the issue to discuss strategy for the Senate. Johnson and Deputy Attorney General Nicholas Katzenbach argued about whether the votes were there to secure cloture in the Senate. Johnson expressed his doubts, but Katzenback insisted they could be there. The meeting ended with the president still in disagreement with Katzenbach about the possibility of getting the votes for cloture. That evening, in the midst of a White House reception, the two men resumed their discussion, with the president adamantly repeating that they could not get the votes. "Mr. President," Katzenback argued, "I think we can." Katzenbach believed that the eight votes needed were there among the eleven waverers he had counted. LBJ agreed to give it a try and called the waverers. Soon after, Katzenbach recalls, LBJ was asked at a press conference, "'What are you going to do with the civil rights bill,' and when Lyndon Johnson, with all his experience in the Senate said, 'We're going to get cloture,' that made it believable." 42 Whether or not the president believed it, he said cloture was attainable, and by saying it he helped make it happen.

President Johnson agreed to include in the pending bill the strengthening amendments that were supported by the civil rights groups. Later, when rumors flew around Washington that Johnson was prepared to compromise on these issues, he called in civil rights leaders and reassured them that he "wanted the bill passed by the House without a word or a comma changed." The president also told Joseph L. Rauh, Jr., a leader of the Leadership Conference on Civil Rights, and Clarence Mitchell, the chief lobbyist for the NAACP, that the bill was going to be passed intact in the Senate, and "we are not going to have anything else hit the Senate floor until this bill is passed." Rauh recalls that this was "the key meeting that convinced me that we were going to get the bill [as it stood] and the President was absolutely committed to it." 43 Publicly and privately, Johnson reiterated his absolute commitment to getting the strengthened bill through the Congress. ${ }^{44}$ In the spring of 1964, for the first time in the history of the U.S. Senate, a southern filibuster of civil rights legislation was broken, and that summer Johnson signed the Civil Rights Act of 1964 into law.

Within months of the passage into law of the Civil Rights Act of 1964, Johnson speedily moved to get voting-rights legislation before Congress and enacted into law. Martin Luther King, Jr., spoke with the president on 18 December 1964 about the possibility of voting-rights legislation and the commencement of demonstrations in Selma, Alabama, in January 1965. Johnson was aware of the pending demonstrations before the black 
activist had spoken to him and, no doubt, the prospect of the Selma demonstrations helped prod LBJ into action. ${ }^{45}$ But another factor that moved Johnson to grapple with southern black voting rights was the 1964 presidential election results in the South. Nationally, the Gallup polls in 1964 consistently showed Johnson winning the presidential contest against GOP nominee Barry Goldwater by a wide margin. The polls also indicated strong public approval, by a 57 percent to 21 percent margin, for LBJ's civil rights policies. ${ }^{46}$ But the political alignment of a hundred years was altered as Johnson narrowly lost the overall southern popular vote, 49 percent to 48.9 percent, and overwhelmingly lost the Deep South black-belt region. 47

In the fall of 1964, Larry O'Brien, Johnson's top political operative, took a six-week trip across the country to assess the state of the electorate for his chief. His report, the "Negro Vote in the South," was a blockbuster. ${ }^{48}$ Bill Moyers recalls that the report became "critical" to LBJ's thinking. ${ }^{49} \mathrm{O}^{\prime} \mathrm{Brien}$ reported that the president's victory in at least six of the southern states "hinges upon the percentage of Negro voters who go to the polls on Nov. 3." He argued that over 90 percent of blacks will vote for LBJ, "if they vote." The Democratic National Committee and some southern black leaders recognized the importance of the 2.1 million southern black voters, but many southern white Democratic leaders were going to have to rethink their relationship to the black electorate. O'Brien argued: "If white Democratic leaders would assure Negroes that they really want them to vote... it would go a long way toward relieving some Negroes of deep-rooted fears about the possible consequences of voting in the election."

Black votes were now critical to a Democratic presidential victory in much of the South. They were going to become more critical as southern white Democrats continued their flight out of the presidential column. O'Brien recalled, "It just hit him between the eyes. It really targeted the political problems. It really projected the problems we faced in the future with party realignment. He had the South in '64. We knew that. But the future was what he was seeing." O'Brien added: "It's almost like to Johnson I went out and found some key to some lock." To him, O'Brien had put in some coherent form something that was absolutely pivotal to the Democrats and to him. ${ }^{50}$ The Democratic party had been the South's party for more than a century because of its commitment to white supremacy; now the party would remain competitive in the South only with the help of black voters.

On 17 November, two weeks after the 1964 election was held, Louis Martin, a well-respected black member of the Democratic National Com- 
mittee, wrote a memorandum, "Operation Dixie, 1964-1965," to John Bailey, the DNC chairman. Martin emphasized that the party had to begin a massive black voter-registration drive, with special concentration in the five states carried by Goldwater, and that new federal voterregistration legislation had to be seriously considered. ${ }^{51}$ In December, Matthew A. Reese, Jr., director of operations for the DNC, sent to the White House a confidential report that noted, "It should be recognized that the first step toward getting out a big Democratic vote is to increase [Negro] registration." ${ }^{52}$ Thus, when King came to speak with Johnson about the pending voting-rights campaign, he was speaking with someone who was keenly aware of his political party's future need for these votes. LBJ moved swiftly as the events in Selma played themselves out in the first half of 1965 . He wanted to stay one step ahead of events, but the crescendo of Bloody Sunday came before his voting-rights proposals were ready for the Congress.

In 1959, the Report of the United States Commission on Civil Rights found that voting litigation was not a viable remedy for southern-state exclusion of blacks from the ballot box. The commission recommended that a system of federal voting registrars be developed to register black voters in the South. ${ }^{53}$ The executive branch of the federal government did not grapple with the commission's recommendation until Lyndon Johnson's presidency.

On 28 December acting Attorney General Katzenbach sent a memorandum to the president with three alternative "major legislative proposals" dealing with voting. Two days later, presidential counsel Lee White sent a memorandum to Bill Moyers: "The President has indicated a desire to move forward early next year with a legislative proposal authorizing a Commission to appoint federal officers to serve as registrars for the purpose of registering individuals for federal elections." ${ }^{44}$ In his January 1965 State of the Union Address, LBJ noted, "I propose that we eliminate every remaining obstacle to the right to vote," and, at a confidential "background" news conference following the address, that the president would propose legislative action that would eliminate "absurd literacy tests and unreasonable residential requirements." ${ }_{55}$ But King pushed the president's people to move more quickly on this than they had anticipated.

As the Selma voting-rights demonstrations got under way in early January 1965, LBJ told Katzenbach, "I want you to write the goddamndest, toughest voting rights bill that you can devise." 56 Assistant Attorney General Ramsey Clark remembers, "In early 1965 he [LBJ] was the one who was prodding us to get a voting rights act out, and he was angry that we had been unable to develop the formulas we needed." ${ }^{57}$ As the Justice 
Department struggled to write a voting-rights bill, Justice attorney Harold Barefoot Sanders recalled, "The instructions as I understood them from the White House ... [ [were] just, 'get a bill up here that will work,' because what we had wasn't working." It was not working "because you had to litigate every lawsuit. What you had to have . . . would by-pass the litigation, in effect, and put the presumption in favor of the voter. In other words, which would say that everybody can vote if he [sic] fulfills certain minimum requirements." 58

In the wake of Bloody Sunday, 7 March 1965, when Alabama state troopers and sheriff's officers viciously attacked Selma's voting-rights marchers, LBJ met with Alabama's Governor George Wallace at the White House, and he told a televised news conference, "This Monday I will send to Congress a request for legislation." ${ }^{59}$ On 17 March, a votingrights bill, whose content was agreed upon by the administration, Senate Majority Leader Mike Mansfield, and Senate Minority Leader Everett Dirksen, was sent to the Hill. The bill had sixty-six co-signers when it went to the Senate, and it was assured of passage from the outset of its introduction into the Congress.

When the bill was dispatched to the Senate Judiciary Committee, its chairman, James Eastland of Mississippi, informed his colleagues, "This would apply to only five states. It is sectional legislation."60 He was right. It was innovative, Reconstruction legislation with the flavor of a postCivil War measure, and Johnson unequivocally supported the proposal. He believed this bill had to be enacted into law if the southern Black disenfranchisement was to be ended. The day before Johnson signed the Voting Rights Act of 1965, Georgia's Senator Richard Russell, the longtime de facto southern leader and LBJ confidante, wrote of his former protégé's civil rights stance: "Our opinions are so completely at variance that we do not discuss what I regard as his extreme position on this issue." 61 Johnson had become an advocate of the toughest civil rights legislation that almost anyone had imagined possible. When asked at one of his last presidential news conferences what he regarded as his "greatest accomplishment," Johnson responded, "The Voting Rights Act."62

\section{Comparing the Kennedy and Johnson Civil Rights Legislative Strategies}

John F. Kennedy and Lyndon Johnson both handled civil rights as a highly charged, volatile issue. For the Kennedy presidency, civil rights 
was an issue that offered few rewards and was fraught with many perils for his presidency. For Johnson, civil rights held ample rewards for his presidency, although he understood that it also held perils for his administration and his political party. Both presidents grappled with defining the issue and the manner and timing when it would be dealt with in the legislative realm.

Although John Kennedy sometimes came under fire from the liberal wing of the Democratic party because of his occasional nonliberal positions, for example, his placement of Johnson on the Democratic ticket, the liberals were bound to him. He was their presidential nominee. Lyndon Johnson came to the presidency because of an assassin's bullet. His party base had always been with the moderate and southern Democratic elements. Civil rights was a critical liberal issue in the two decades following World War II, and by becoming the champion of civil rights Johnson ameliorated the long-standing animosity that most major liberal Democrats felt toward him. When he made his first presidential address before a joint session of Congress, he invited Mayor Robert Wagner of New York City and liberal historian and devoted Kennedy ally Arthur Schlesinger, Jr., to sit with Mrs. Johnson in the House gallery. He believed he needed the liberals' support because they were a dominant element in the Democratic party, and he used the pending civil rights bill to move quickly and with certainty to win their allegiance.

Kennedy came to the presidency with a narrow electoral margin and an unformed sense of how to deal with the Congress and civil rights. "He didn't really know what was possible and what wasn't in Congress," wrote NAACP Executive Secretary Roy Wilkins. "He was always hesitating, weighing what he could and could not do. I don't believe he ever understood the South [or Congress]." 63 Time and again he was pushed into moving forward on civil rights by the activists outside the institutionalized political arena. He supported a major civil rights bill because the Birmingham demonstrations left him little choice to do otherwise. When he had the opportunity to support an even stronger bill, he retreated to the safer, weaker proposals. His public words in June 1963 were of a strong commitment to civil rights, but he believed he could only proceed cautiously. $\mathrm{He}$ feared the desertion of his moderate Democratic and Republican allies. He feared the effects of southern congressional retribution that would flow from his support for black rights.

Johnson came to the presidency with the reputation of being a master of the legislative process, and he knew how to use the windows of political opportunity that came his way. He used Kennedy's martyrdom to rally the public and the Congress to his presidency and its causes. He cajoled, 
promised, and bluffed the congressional fence-straddlers to support the 1964 civil rights proposals. With Johnson's leadership and the active promotion of the civil rights lobbyists, the southern filibuster was broken and a major civil rights bill was enacted into law. After the 1964 presidential election was over, Johnson understood that the Democratic party would be in need of new southern black allies as many of its white southern supporters moved into the GOP voting column. He used the Selma crisis to move forward with the federal enfranchisement of the southern black populous.

Neither Kennedy nor Johnson came to the presidency as a civil rights radical or as a transformer of the political system. Quite the opposite could be inferred from their prepresidential records. Kennedy was a moderate tied to a highly pragmatic, rational view of politics and public policy. Johnson was a moderate tied to majority building and Senate caucus politics. Civil rights was not a major Kennedy concern before he became president, and at the outset of his presidency he made it clear that civil rights legislation was not a priority item on his administration's agenda. Civil rights was an issue that Johnson repeatedly voted against in his early congressional days and later compromised on as Senate majority leader. President Johnson, however, immediately seized upon civil rights legislation as a top-priority concern for his administration. As president, Kennedy and Johnson were each moved by their own prior experiences, as well as by the dynamics of election, the shifting of coalition alliances, and the momentum of the issue outside their control. The convergence of each president's strategic needs with the needs of the civil rights movement produced the enactment of the major civil rights legislation of the Second Reconstruction.

University of Central Florida

\section{Notes}

1. Betty Glad, "The Idiosyncratic Presidency: Contingency and the Use of Case Studies and Synthetic Proofs in Scientific Analysis," Presidential Address, Presidency Research Group, presented at the 1990 Annual Meeting of the American Political Science Association, San Francisco.

2. Anthony Downs, An Economic Theory of Democracy (New York, 1957), 28, 34-35.

3. Nelson Polsby, Political Innovation in America (New Haven, 1984), 161.

4. Jack Walker, "A Critique of the Elitist Theory of Democracy," American Political Science Review 60 (1966): 292.

5. E. E. Schattschneider, The Semi-Sovereign People (Hinsdale, Ill., 1975), 7I.

6. John W. Kingdon, Agendas, Alternatives, and Public Policies (Boston, 1984), 3-4; 
Polsby, 165-74; Anthony Downs, "Up and Down with Ecology: 'The Issue Attention Cycle," "Public Interest 28 (1972): 38-50.

7. William H. Riker, Liberalism Against Populism (San Francisco, 1982), 209.

8. Herbert H. Hyman and Paul B. Sheatsley, "Attitudes Toward Segregation," Scientific American 195 (1956): 35, 39; Hazel Gaudet Erskine, "The Polls: Race Relations," Public Opinion Quarterly 26 (1962): 137-48.

9. Robert Weissberg, "The Democratic Party and the Conflict over Racial Policy," Benjamin Ginsberg and Alan Stone, eds., Do Elections Matter? (Armonk, N.Y., 1991): $150-70$.

10. Among the major works that contain analyses of John F. Kennedy and civil rights, the following are more positive about the Kennedy civil rights role: Irving Bernstein, Promises Kept (New York, 1991); Carl M. Brauer, John F. Kennedy and the Second Reconstruction (New York, 1977); Theodore Sorensen, Kennedy (New York, 1966); Arthur M. Schlesinger, Jr., A Thousand Days (New York, 1965). The following tend to be more critical: Taylor Branch, Parting the Waters (New York, 1988); Adam Fairclough, To Redeem the Soul of America (Athens, Ga., 1987); David J. Garrow, Bearing the Cross (New York, 1986); Steven F. Lawson, Black Ballots (New York, 1976); Bruce Miroff, Pragmatic Liberalism (New York, 1976); Victor S. Navasky, Kennedy Justice (New York, 1977); Mark Stern, Calculating Visions (New Brunswick, N.J., 1992).

11. See Robert F. Burk, The Eisenhower Administration and Black Civil Rights (Knoxville, Tenn., 1984); J. W. Anderson, Eisenhower, Brownell, and the Congress (University, Ala., 1964); Steven F. Lawson, Black Ballots (New York, 1976).

12. U.S. Senate Committee on Commerce, Report: Speeches, Remarks, Press Conferences, and Statements of Senator John F. Kennedy, 87th Cong., 1st sess. (Washington, D.C., 1961), 69; Press Release, "From the Offices of Senator Joseph F. Clark (D.-Pa.) and Representative Emanuel Celler (D.-N.Y.)," 16 September 1960, Papers of Emanuel Celler, Box 272, Library of Congress. (Hereafter the Library of Congress is referred to as LC.)

13. Arthur M. Schlesinger, Jr., to John F. Kennedy, 30 August 1960, Papers of Adlai Stevenson, Box 798, Princeton University Library.

14. Eleanor Roosevelt is quoted in: Arthur Schlesinger, Jr., to John F. Kennedy, 14 November 1960, JFK, President's Office Files, Box 165, John F. Kennedy Library. (Hereafter the Kennedy library is referred to as JFKL.)

15. Sorensen, 382; Robert F. Kennedy, Oral history interview by John Bartlow Martin, 29 February 1964, JFKL, 44.

16. D. B. Hardeman and Donald C. Bacon, Rayburn (Austin, Tex., 1987), 452.

17. Martin Luther King, Jr., "Bold Design for a New South," The Nation, 30 March 1963, 260; Burke Marshall, Oral history interview by Larry Hackman, 29 May 1964, JFKL, I-46.

18. New York Times, 12 June 1963.

19. Burke Marshall, Oral history interview, 14 June 1964, JFKL, 101; Norbert A. Schlei, Oral history interview of John Stewart, 20-21 February 1964, JFKL, 44.

20. Sorensen, Kennedy, 494.

21. Milton Viorst, Fire in the Streets (New York, 1983), 221-22; Schlesinger, A Thousand Days, 883.

22. Public Papers of the Presidents of the United States: John F. Kennedy, 1963 (Washington, D.C., 1964), 272. (Hereafter references to the Public Papers of the Presidents . . . will be noted as PPP, followed by the president's initials and the year.)

23. James L. Sundquist, Politics and Policy (Washington, D.C., 1968), 263.

24. Robert F. Kennedy, Oral history interview by Anthony Lewis, 6 December 1963, JFKL, $\mathrm{V}-3$.

25. Schlesinger, A Thousand Days, 884-85.

26. Julius Lester, Look Out, Whitey! Black Power's Gon' Get You Mama! (New York, 1968), 12-13; David Levering Lewis, King (Urbana, Ill., 1970), 219. 
27. Burke Marshall, Oral history interview with Anthony Lewis, 22 December 1964, JFKL, 917-18.

28. New York Times, 29 August 1963.

29. August Meier, "Who Are the 'True Believers'? A Tentative Typology of the Motivations of Civil Rights Activists (1965)," in Joseph R. Gusfield, ed., Protest, Reform, and Revolt (New York, 1970), 480-81.

30. PPP: JFK, 1963, 645; Transcript of "March on Washington . . . Report by Leaders," 28 August 1963, White House Subject Files, Box 365, JFKL.

31. Audiotape log 108.2, White House Subject Files, Box 505, JFKL; Washington Post, 16 October 1963.

32. Arnold J. Aaronson to All Cooperating Organizations, 30 August 1963, Papers of the Leadership Conference on Civil Rights, Organizations File, Box 4, Library of Congress.

33. Joseph L. Rauh, Jr., Interview by Mark Stern, 30 August 1988, transcript in possession of the author, 6 .

34. David Cohen to Beryl Radin, 31 October 1963, Papers of the Americans for Democratic Action, Series V, No. 88, Microfilm Corporation of America; Robert W. Kastenmeier, Oral history interview by Ronald Grele, 25 October 1965, John F. Kennedy Library, 14-15. The most comprehensive analysis of the struggle over the Civil Rights Act of 1964 is: Charles Whalen and Barbara Whalen, The Longest Debate (Cabin John, Md., 1985).

35. This episode is fully described in Whalen and Whalen, The Longest Debate, 35-66.

36. Bayard Rustin to Martin Luther King, Jr., 5 November 1963, Papers of the Southern Christian Leadership Conference, Box 20: 39, Martin Luther King, Jr., Center for Social Change.

37. John A. Blatnik, to Democratic Study Group Members, 13 November 1963, Papers of the Democratic Study Group, Box 72, LC.

38. Jack Valenti, Oral history interview by Mark Stern, 5 October 1990, transcript in possession of the author, 1; Whalen and Whalen, The Longest Debate, 63.

39. PPP: LBJ, 1963-1964, 9.

40. Doris Kearns, Lyndon Johnson and the American Dream (New York, 1976), 199.

41. Harry McPherson, Oral history interview with Mark Stern, 24 July 1989, transcript in possession of the author, 1.

42. President's Appointment File (Diary Backup), 11 February 1964, Box 4, Lyndon Baines Johnson Library; Nicholas deB Katzenbach, "Lyndon Johnson and the Civil Rights Revolution: A Panel Discussion," in Bernard Firestone and Robert C. Vogt, eds., Lyndon Johnson and the Uses of Power (New York, 1988), 179. (Hereafter the Johnson Library is referred to as LBJL.)

43. Joseph L. Rauh, Jr., "Notes on Meeting: President Johnson, Clarence Mitchell, and Joe Rauh," 21 January 1964, Papers of Joseph L. Rauh, Jr., Box 26, LC; Joseph L. Rauh, Jr., Oral History interview by Paige Mulhollan, 8 August 1969, LBJL, 16; Joseph L. Rauh, Jr., Oral history interview by Mark Stern, 28 March 1990, interview in possession of the author, 4.

44. See, for example, PPP: LBJ, 1964, 28, 35; Lyndon Baines Johnson to John M. Hannah, 21 January 1964, Johnson Papers, EX FG 629-1, Box 375, LBJL.

45. The major analysis of King's Selma strategy is by David J. Garrow, Protest at Selma: Martin Luther King, Jr., and the Voting Rights Act of 1965 (New Haven, 1978).

46. George Gallup, The Gallup Poll (New York, 1972), 3:1881, 1894, 1896, 1902; New York Times, 24 August, 6 October, 3 November 1964.

47. Bernard Cosman, Five States for Goldwater (University, Ala., 1965); James L. Sundquist, Dynamics of the Party System (Washington, D.C., 1983), 352-75; Edward G. Carmines and James A. Stimson, Issue Evolution (Princeton, 1989), 188.

48. Larry O'Brien, Memorandum to the President, 23 October 1964, White House Central Files, Office Files of Henry Wilson, Box 3, LBJL.

49. Bill Moyers, Letter to Mark Stern, 27 August 1985, copy in possession of the author. 
50. Lawrence F. O'Brien, Interview by Mark Stern, 19 July 1989, transcript in possession of the author, 11.

51. Louis Martin to John M. Bailey, "Operation Dixie, 1964-1965," 17 November 1964, Johnson Papers, Legislative Background, Voting Rights Act of 1965, Box 1, LBJL.

52. Matthew Reese, Jr., "Voting Participation and Registration," Confidential report, December 1964, Office Files of Fred Panzer, Box 500, LBJL.

53. United States Commission on Civil Rights, Report of United States Commission on Civil Rights (Washington, D.C., 1959).

54. Nicholas deB Katzenbach to Lyndon B. Johnson, 28 December 1964, Justice Department Administrative History, Vol. 7, Part Xa, LBJL; Lee White to Bill Moyers, "Legislation to Facilitate Registration for Federal Elections," 30 December 1964, White House Central Files, Office Files of Lee White, Box 3, LBJL.

55. PPP: LBJ, 1965, 1:5; News Conference, "Background Basis from W.H. Officials," with George Reedy, McGeorge Bundy, and William Moyers, 4 January 1965, Johnson Papers, President, 1963-1969, Legislative Background, Voting Rights Act of 1064, Box 1, LBJL.

56. Howell Raines, My Soul Is Rested (New York, 1983), 337.

57. Ramsey Clark, "Comment," in Firestone and Vogt, eds., Lyndon Johnson and the Uses of Power, 174. 3.

58. Harold Barefoot Sanders, Oral history interview by Joe B. Frantz, Tape no. 3, LBJL,

59. Lyndon B. Johnson, The Vantage Point (New York, 1971); 163; PPP: LBJ, 1965, 274-81.

60. Congressional Record, 89th Cong., 1st sess., 18 March 1965, 5228.

61. Richard B. Russell to Zac Crittenden, 5 August 1965, Richard B. Russell Papers, Political Series, VI:23, Richard B. Russell Library.

62. PPP: LBJ, 1968, 1354.

63. Roy Wilkins and Tom Mathews, Standing Fast (New York, 1984), 196. 